\title{
PENERAPAN GOOD POLITICAL GOVERNANCE SEBAGAI UPAYA TRANSPARANSI DANA PARTAI POLITIK
}

\author{
Evi Malia ${ }^{1}$ \\ ${ }^{1}$ Universitas Islam Madura, Indonesia \\ 1evi.malia@uim.ac.id
}

\begin{abstract}
All Political Parties have fulfilled the Receipt and Use of Campaign Funds (LPPDK) reports, because if they are not fulfilled, they will get sanctions based on KPU Regulations. The preparation of these various reports shows that political parties are obliged to demonstrate good governance to the public, in order to form a stigma that political parties have high accountability with a high level of transparency. However, in reality this is not directly proportional to the daily governance of political parties. This study uses a qualitative research method with an interpretive approach, where data collection uses data triangulation. As for the results of the research, namely the rules that cover political parties are clear, but their application has not been implemented as the existing legal umbrella, namely law. Unlike the case with the implementation of elections related to campaign funds. Realizing good political party governance must start from the awareness of party officials to always present data and reports in a transparent manner, not only obeying during elections but continuously and continuously. Not only afraid of direct sanctions imposed by the KPU, but also pay attention to the continuity and sustainability of political parties. Going concern does not only apply to business entities, but it is also important to apply to political party organizations. Political parties are a gathering place for cadres who become and or will still be public officials who later carry out the mandate and work for the people, this is the reason for the importance of accountability and transparency for good party governance.
\end{abstract}

Keywords : Good Political Party Governance, Political Party Funds, Transparency, Accountability

\section{PENDAHULUAN}

Pemilihan Umum (Pemilu) Tahun

2019 telah selesai dilaksanakan 6 bulan yang lalu, dengan Presiden Joko Widodo dan KH. Makruf Amin sebagai Wakil Presiden terpilih. Pelaksanaan Pemilu tidak terlepas dari keikutsertaan Partai Politik (Parpol) sebagai peserta pesta demokrasi tersebut. Parpol dalam keiikutsertaaanya pada pemilu membutuhkan dana sebagai modal dan biaya untuk memenuhi target jabatan yang dituju oleh anggota Parpol maupun utusan parpol. Dana Pemilu yang biasa disebut dengan dana kampanye pemilu diwajibkan utuk dibuat laporan pertanggung jawabannya, baik dana yang diperoleh ataupun dana yang digunakan oleh Parpol.

Berdasarkan Undang-undang No. 02 Tahun 2011 Tentang Perubahan Atas Undang-undang N0. 02 Tahun 2008 Tentang Partai Politik, bahwasanya sumber dana partai politik dapat diperoleh melalui 3 (tiga) sumber yaitu, yang pertama melalui iuran anggota, 
yang kedua melalui sumbangan yang sah menurut hukum, dan yang ketiga yaitu melalui bantuan keuangan dari APBN dana APBD. Hal ini selaras dengan Peraturan Komisi Pemilihan Umum (PKPU) No 24 Tahun 2018 tentang Dana Kampanye Peilihan Umum yang menetapkan dana kampanye berasal dari tiga sumber yaitu berasal dari pasangan calon presiden dan wapres ataupun caleg DPR dan DPRD masing-masing yang diusung partai, Partai Politik maupun gabungan partai politik, dan sumbangan yang diperbolehkan dan sah menurut hukum. KPU (Komisi Pemilihan Umum) telah membuat aturan mengenai pertanggung jawaban mulai dari kewajiban partai politik menunjuk tim kampanye lalu membuka Rekening Dana Kampanye (RKDK) untuk dana kampanye berupa uang dan melaporkannya, kemudian tim kampanye membuat Laporan Awal Dana Kampanye (LADK) kepada KPU. Setelah itu, atas dana kampanye yang diterima tim kampanye membuat Laporan Penerimaan Sumbangan Dana Kampanye (LPSDK), dan terakhir tim kampanye menyusun Laporan Penerimaan dan Penggunaan Dana Kampanye (LPPDK). Rangkaian penyusunan berbagai macam laporan tersebut menunjukkan bahwa partai politik wajib menunjukkan tatakelola yang baik kepada publik, agar terbentuk stigma bahwa partai politik memiliki akuntabilitas yang tinggi dengan tingkat transparansi yang tinggi pula.

Namun kenyataannya, apakah kepatuhan partai politik kepada KPU pada saat Pemilihan Umum (Pemilu) berbanding lurus dengan kepatuhannya untuk menyajikan data yang tepat dan akurat. Wibowo (2018) menyatakan bahwasanya berasarkan hasil audit kepatuhan dana kampanye pada tahun 2014 diperoleh sebanyak 7 partai dari 12 partai yang memiliki kategori kepatuhan tinggi, 3 partai dengan kepatuhan sedang, dan 2 partai dengan kepatuhan rendah. Kepatuhan ini hanya diukur dari kepatuhan laporan penerimaan dan penggunaan dana kampanye, artinya tatakelola harian partaipun perlu dihimbau untuk ditindak lanjuti. Publik harus peka terhadap transparansi dana partai politik. Tahun 2019 LPPDK harus masuk ke KPU sejak tanggal 17 April sampai terakhir 02 Mei 2019, namun dalam beberapa artikel dan portal berita hingga 3 Mei masih terdapat beberpa partai di daerah yang tidak menyerahkan laporannya, hal ini meunjukkan bahwa kesadaran parpol untuk patuh terhadap aturan KPU masih rendah. Hasil audit dana kampanye tahun 2019 menunjukkan bahwasanya terdapat 9 partai yang masuk kategori tidak patuh, dan hanya 7 partai yang masuk kategori patuh, temuan ketidak patuhan tersebut 
mayoritas berasal dari dana kampanye yang bersumber dari dana pribadi caleg tidak dimasukkan kedalam RKDK (Kompas.com:2019), artinya Pemilu tahun 2019 tidak banyak memberikan perubahan bagi tatakelola dana kampanye dimana pada Pemilu tahun 2014 juga hanya terdapat 7 Partai Politik yang yang memiliki tingkat kepatuhan tinggi.

Undang-undang No. 2 tahun 2008 pasal 37 dan 38 bahwa parpolwajib membuat laporan pertanggungjawaban peneriimaan dan pengeluaran keuangan parpol yang di audit dan wajib dipublikasikannya kepada masyarakat. Masyarakat perlu mengontrol program dan dan parpol sesuai amanat UU, namun sampai saat ini sudahkah masyarakat diberikan pendidikan politik yang baik dan memadai sebagai wujud kontrol publik terhadap partai politik. Sementara laporan pertanggung jawaban parpol belum ada pedoman baku yang harus diikuti, namun secara umum patai politik mengikuti pedoman Akuntansi Nirlaba yang telah diatur dalam PSAK 45 dalam pelaporannya.

Penelitian yang dilakukan oleh wibowo (2018) yang berjudul Akuntabilitas Partai Politik dan Elektabilitas Partai Politik dengan studi kasus di propinsi Yogyakarta pada Tahun 2014 yang menghasilkan dua Indikator yaitu Akuntabilitas dan Dana
Kampanye. Dimana Akuntabilitas Parpol hanya ditujukkan dengan adanya hasil audit yang dilakukan oleh KAP dimana audit tersebut hanya mrnyangkut audit kepatuhan saja.Sementara itu,jika kita hanya berfokus pada audit kepatuhan maka hal tersebut tidak menggambarkan kualitas laporan dan pelaporan keuangan partai politik secara menyeluruh. Serta dengan tidak terdapatnya standard yang baku dalam menyusun laporan keuangan pada partai politik juga akan menyebabkan tidak terpenuhinya syarat perbandingan laporan keuangan, atau dengan kata lain tidak diperbandingkan baik dengan entitas yang sama maupun antar periode waktu.

Penelitian mengenai mendorong transparansi dan akuntabilitas pengaturan keuangan partai politik dilakukan oleh panilih (2017) yang menghasilkan praktik pengumpulan dana oleh parpol dengan tidak berdasarkan prinsip transparansi dan akuntabilitas akan berakibat adanya berbagai kasus dugaan korupsi yang dilakukan oleh anggota parpol. Banyak kasus korupsi yang terungkap bahwa penggunaan dana pemenangan pemilu berasal dari dana korupsi mulai tingkat daerah hingga nasional. Sehingga perlu adanya reformasi regulasi pengelolaan keuangan partai politik yang memenuhi prinsip akuntabilitas dan transparan, hal 
ini bisa dicapai dengan cara mewajibkan partai politik melaporkan sumber dana yang diperoleh baik dari iuran anggota parpol, dan APBN dan APBD maupun sumbangan pihak ketiga. Selain itu, parpol juga perlu membuat laporan dana pemilu termasuk didalamnya yaitu dana kampanye. Pembuatan laporan terebut perlu adanya standar laporan keuangan partai sehingga akan terjadi keseragaman pemahaman antar partai politik yang lengkap beserta pengaturan sanksi yang tegas dan di adopsi kedalam undang-undang pemilu dan undangundang partai politik.

Secara filosofis, partai politik dibentuksebagai wujud nyata kedaulatan rakyatbukan wujud nyata kekuatan ekonomi. Oleh sebab itu, perlu pembatasan sumber keuangan partai politik untuk mencegah penyalahgunaan uang demi kepentingan politik. Jika partai politik punya komitmen untuk bersikap transparan dalam pengelolaan keuangannya, hal tersebut akan menjadi daya Tarik sendiri bagi masyarakat dalam memberi kepercayaan kepada parpol. Peran dan fungsi akuntansi bagi partai politik dapat dilihat dari dua aspek yaitu pihak internal dan pihak eksternal, dimana pihak internal meliputi ketua parpol, Staf, dan anggota parpol. Sedangkan pihak eksternal yaitu Donatur, Kreditur, Konstituen, BPK, dan Pemerintah. (Halim dan Kusufi : 2018).

Sehingga timbullah permasalahan dalam penelitian ini yaitu bagaimana penerapan good political party governance dalam upaya mewujudkan transparansi dana partai politik.

\section{METODE}

Metode penelitian yang digunakan dalam penelitian ini adalah metode penelitian kualitatif dengan pendekatan interpretif. Paradigma interpretif mmerupakan paradigma fenomenologi atau naturalistik menurut patton dalam rahardjo (2018) menjelaskan Paradigma interpretif yang memandang realitas sosial secara holistik, tidak terpisah-pisah, kompleks, dinamis, penuh makna, dan hubungan antar gejala bersifat timbal balik. Paradgm interpretif mengungkapkan bahwa ilmu pengetahuan diperlukan untuk memaknai dan memahami realitas (subjektif) Jenis penelitian deskriptif kualitatif yang digunakan pada penelitian ini dimaksudkan untuk memperoleh informasi mengenai akuntabilitas partai politik di Kabupaten pamekasan. Penelitian ini dilaksanakan di Kabupaten Pamekasan dengan cara mengumpulkan data partai politik peserta pemilu diperwakilan kabupaten Pamekasan.

Jenis data dalam penelitian ini ada dua macam, yaitu jenis data primer 


\section{FAKULTAS EKONOMI DAN BISNIS UNIVERSITAS WIRARAJA - MADURA}

melalui cara observasi dan wawancara dengan perwakilan pengurus partai politik di Kabupaten Pamekasan. Selain menggunakan data primer, penelitian ini juga menggunakan data sekunder, yaitu dengan cara studi literatur mengumpulkan dokumen yang diperkan sebagai data pembanding yang bersumber dari media.

Teknik Analisis Data yang digunakan dalam penelitian ini menggunakan teori Miles and Huberman (dalam Agusta 2003) ada 3 tahapan yaitu:

1. Reduksi Data

Reduksi datayang dilakukan oleh peneliti yaitu melalui wawancara terkait dengan informan yang berhubungan dengan perencanaan yang fokusnya kepada:

\section{a. Laporan Keuangan Partai Politik.}

b. Ketersedian data parpol, mulai dari prgram, kaderisasi, dan laporan keuangan penermaan dan pengeluaran dana partai politik.

\section{Penyajian Data}

Proses kedua setelah reduksi data adalah penyajian data. Dalam penelitian kualitatif penyajian data biasanya disajikan dalam bentuk tabel, flow chart, diagram, grafik, dan sejenisnya. Penyajian data dalam penelitian ini dilakukan dengan cara

$\begin{array}{lcr}\text { bagaimana } & \text { pengurus } & \text { parpol } \\ \text { memandang } & \text { suatu } & \text { konsep } \\ \text { akuntabilitas dan } & \text { melakukan } \\ \text { pertanggungjawaban } & \text { dana } & \text { partai } \\ \text { politik. } & & \end{array}$

3. Membuat Kesimpulan.

Membuat sebuah kesimpulan dalam penelitian harus menjawab rumusan masalah yang dirumuskan sejak awal tetapi mungkin saja tidak. Kesimpulan atau verifikasi dalam penelitian ini akan menghasilkan penjelasan dan pernyataan bagaimana sebenarnya tingkat transparansi dan akuntabilitas partai politik, baik dari segi tatakelola dan peaporan tahunan partai politik maupun berkaitan dengan pertanggung jawaban dana kampanye.

\section{HASIL PENELITIAN}

Berdasarkan pengumpulan data yang telah dilakukan, maka dapat disajikan data penelitian sesuai dengan indikator yang telah ditetapkan. Adapunpeneltian ini dilakukan pada 16 partai politik peserta pemilu yang ada di Kabupaten Pamekasan.Partai politik peserta pemilu pada tahun 2019 berjumlah 16 partai mulai dari partai nasional hingga partai local seperti partai di Aceh. Mulai partai lama hingga partai yang baru berdiri seperti Partai Solidaritas Indonesia (PSI) (infopemilu.kpu.go.id) 
Penelitian ini ingin mengungkap sejauh mana akuntabilitas dan tingkat transparansi partai peserta pemilu 2019, mengingat pelaksanaan pemilu telah selesai hampir setahun yang lalu. Jika dilihat secara nasional hasil audit kepatuhan laporan keuangan dana kampanye dapat dikategorikan baik, karena Secara administrasi memang masih terdapat 8 parpol yang tidak patuh secara administratif yaitu, partai tidak melaporkan penyumbang dana secara lengkap namun patuh dalam pengelolaan pelaporan dana kampanye. (Kompas : 2019)

Sedangkan yang terjadi di Kabupaten Pamekasan yaitu Pada tanggal 07 Mei 2019, Partai Garuda belum menyetorkan Laporan

Penerimaan dan Pengeluaran Dana

Kampanye kepada KPU Kabupaten

Pamekasan (TribunMadura.Com : 2019)

Sehingga pada saat melakukan observasi dan pengumpulan data diperoleh informasi seperti tercantum dalam tabel 4.1. pengumpulan data dilakukan melalui observasi ke kantor perwakilan partai di kabupaten pamekasan dan melakukan wawancara terstruktur dan pengumpulan data sekunder melalui dokumentasi laporan dan dokumen yang diperlukan

Tabel. 4.1

Keterbukaan akses data pada perwakilan Parpol di Kabupaten Pamekasan

\begin{tabular}{|l|l|l|l|l|l|}
\hline No & $\begin{array}{c}\text { Nama } \\
\text { Partai }\end{array}$ & $\begin{array}{c}\text { Laporan } \\
\text { Keuangan }\end{array}$ & $\begin{array}{c}\text { AD/ } \\
\text { ART }\end{array}$ & \multicolumn{1}{|c|}{ Sumber Dana } & Keterangan \\
\hline 1 & PKS & - & $\sqrt{ }$ & Sesuai UU & \\
\hline 2 & Nasdem & - & $\sqrt{ }$ & APBN/APBD & LK Bersifat Internal \\
\hline 3 & Gerindra & $\sqrt{ }$ & $\sqrt{ }$ & APBN/APBD & WDP \\
\hline 4 & PDI P & - & $\sqrt{ }$ & Gotong Royong & \\
\hline 5 & PKB & - & $\sqrt{ }$ & Bakesbangpol & \\
\hline 6 & PKPI & - & $\sqrt{ }$ & Sesuai UU & \\
\hline 7 & PSI & - & $\sqrt{ }$ & $\begin{array}{l}\text { Perseorangan/Bad } \\
\text { an }\end{array}$ & LK Bersifat Internal \\
\hline 8 & Golkar & - & $\sqrt{ }$ & $\begin{array}{l}\text { APBN, APBD \& } \\
\text { Iuran Anggota }\end{array}$ & \\
\hline 9 & PAN & $\sqrt{ }$ & $\sqrt{ }$ & APBN dan APBD & Rencana kerja dan \\
& & & $\sqrt{ }$ & Sesuai UU & - \\
\hline 10 & Demokrat & - & $\sqrt{ }$ & Iuran Anggota & \\
\hline 11 & Garuda & - & $\sqrt{ }$ & APBN \& APBD & \\
\hline 12 & PBB & - & $\sqrt{ }$ & Perseorangan & \\
\hline 13 & Perindo & - & $\sqrt{ }$ & APBN/APBD & \\
\hline 14 & Hanura & - & $\sqrt{ }$ & Bakesbangpol & \\
\hline 15 & Berkarya & - & - & &
\end{tabular}

Sumber : Data diolah (2020) 
Tabel. 4.2.

Daftar Partai Politik Peserta Pemilu Tahun 2019 yang menyerahkan LPPDK

\begin{tabular}{|l|l|l|}
\hline No & \multicolumn{1}{|c|}{ Nama Partai } & \multicolumn{1}{|c|}{ Caleg yang Menyerahkan } \\
\hline 1 & PKS (Partai Keadilan Sejahtera) & 531 \\
\hline 2 & Nasdem & 575 \\
\hline 3 & Gerindra & 575 \\
\hline 4 & PDI P & $572 / 1$ \\
\hline 5 & PKB & $572 / 3$ \\
\hline 6 & PKPI & $137 / 3$ \\
\hline 7 & PSI & $573 / 1$ \\
\hline 8 & Golkar & $570 / 4$ \\
\hline 9 & PAN & 575 \\
\hline 10 & Demokrat & $453 / 119$ \\
\hline 11 & Garuda & $225 / 1$ \\
\hline 12 & PBB & 484 \\
\hline 13 & Perindo & $346 / 222$ \\
\hline 14 & Hanura & $424 / 3$ \\
\hline 15 & Berkarya & $545 / 7$ \\
\hline 16 & PPP & $360 / 194$ \\
\hline
\end{tabular}

Sumber. Kompas Nasional (2019)

Dari 16 parpol yang menjadi objek dalam penelitian ini, hanya 1 (satu) parpol yang bersedia memberikan Laporan Keuangan yaitu pantai Gerindra. Namun Laporan Keuangan tersebut merupakan laporan keuangan pusat yang sudah diaudit dan sudah di publish, sementara ada satu partai lagi yang hanya memberikan laporan anggaran dan program kerja yaitu partai Amanat Nasional (PAN).

Sedangkan laporan Dana kampanye, baik pusat maupun daerah kompak untuk mematuhi aturan KPU maupun Bawaslu hal ini dibuktikan dengan adanya laporan KPU bahwa mayoritas Parpol kompak melaporkan LPPDK.
Transparansi memiliki beberapa dimensi, menurut mardiasmo (2009) sebagai berikut:

1. Informativeness (Informatif), indikator informatif yaitu:

a. Tepat waktu, LPPDK harus dsampaikan tepat waktu ke KPU.

b. Memadai, informasi yang disampaikan harus lengkap.

c. Jelas, tidak menganung unsur ambiguitas.

d. Akurat, dapat dipertanggungjawabkan

e. Dapat diperbandingkan

f. Mudah di akses, semua masyarakat yang berkepentingan dapat mengakses informasi tersebut dengan mudah.

2. Disclosure (pengungkapan), yang perlu diungkapkan yaitu:

a. Kondisi keuangan 
b. Susunan pengurus

c. Bentuk perencanaan dan hasil dari kegiatan

Berdasarkan teori informasi yang dikemukakan oleh mardiasmo, hal yang diakukan oleh para pengurus partai politik memang mencoba untuk menunjukkan bahwa parpolnya telah bersikap transparan, namun sikap yang ditunjukkan oleh pengurus partai menunjukkan hal yang sebaliknya, terbukti dengan informasi yang diberikan mereka bersikap seolah-olah terbuka dengan memberikan $\mathrm{AD} / \mathrm{ART}$ parpol yang memang sudah jelas di publish, namun mereka tidak bersedia memberikan laporan keuangan ataupun laporan dana kampanye kepada masyarakat.

Pertanggungjawaban partai politik ditujukan kepada publik, karena Partai Politik merupakan organisasi publik, Undang-undang No. 2 tahun 2008 pasal 37 dan 38 menyatakan bahwa partai politik wajib membuat laporan pertanggungjawaban penerimaan dan pengeluaran keuangan parpol yang di audit dan wajib dipublikasikannya kepada masyarakat . Publikasi yang dimaksud bisa dalam berbagai bentuk dan media. Masyarakat perlu tau kaderisasi parpol dan kinerja parpol sebagai gambaran masyarakat untuk memilih partai mana yang dapat mewakil aspirasinya. Menurut cirus surveyor group (CSG) dalam Dwikora (2016) hampir semua partai politik di Indonesia tidak menjalankan fungsinya, seperti penyampaian program, kaderisasi, keterbukaan sumber dana dan pengeluarannya, hubungan politisi dengan konstituennya dan penyuluhan demokrasi seharusnya dilakukan.

Secara organisasi, partai politik merupakan organisasi nirlaba atau organisasi sktor publik. Salah satu ciri organisasi sektor publik yaitu pertanggungjawabannya kepada publik sebagai stakeholder. Dari sekian banyak Partai Politik hanya segelintir jumlah partai yang melaksanakan pertanggung jawabannya dengan baik. Pada laman situs resmi (website) partai, hanya mencantumkan laporan keuangan yang telah diaudit BPK dan berasal dari dana APBN seperti yang dilakukan oleh partai PKB pada lamannya http://pkb.id, sebagian parpol mencantumkan dana parpol sendiri yang bersumber dari kader dan lainnya selain yang bersumber dari APBN terdapat laporan tersendiri, namun hanya sebagian saja seperti PDIP pada laman website http://www.pdiperjuangan.id .

Pada kondisi partai politik didaerah seperti Kabupaten Pamekasan juga didapatkan bahwasanya publik tidak bisa mengakses laporan keuangan Partai Politik. Dari 16 Parpol hanya ada 2 (dua) Partai Politik yang memberikan 


\section{FAKULTAS EKONOMI DAN BISNIS UNIVERSITAS WIRARAJA - MADURA}

Laporan Keuangannya sementara sisanya tidak bersedia memberikan karena hal tersebut bersifat rahasia. Berdasarkan teori informasi yang dikemukakan oleh mardiasmo, hal yang diakukan oleh para pengurus partai politik memang mencoba untuk menunjukkan bahwa parpolnya telah bersikap transparan, namun sikap yang ditunjukkan oleh pengurus partai menunjukkan hal yang sebaliknya, terbukti dengan informasi yang diberikan mereka bersikap seolah-olah terbuka dengan memberikan AD/ART parpol yang memang sudah jelas di publish, namun mereka tidak bersedia memberikan laporan keuangan ataupun laporan dana kampanye kepada masyarakat.

Aturan yang menaungi Parpol sudah jelas, namun penerapannya belum diterapkan sebagaimana payung hukum yang telah ada yaitu Undang-undang. Beda halnya dengan pelaksanaan pemilu yang berkaitan dengan dana kampanye. Secara tegas, KPU menyatakan tidak akan melantik anggota dewan terpilih jika parpolnya belum melaporkan LPPDK. Ketentuan tersebut termaktub dalam undang-undang Nomor 7 tahun 2017 tentang Pemilu dalam pasal 338 ayat 3 bahwasanya apabila pengurus parpol peserta pemilihan umum tidak menyampaikan Laporan Penerimaan dan Pengeluaran Dana Kampanye kepada
KAP yang ditunjuk oleh KPU sampai batas waktu yang ditentukan maka dikenai sanksi berupa tidak dapat ditetapkannya calon anggota DPR, DPRD Provinsi, dan DPRD Kabupaten menjadi calon terpilih.

Sekolah poitik sangat penting diterapkan bagi kader Parpol, agar semua kader Parpol memahami pentingnya pertanggung jawaban yang transparan bagi publik. Parpol merupakan organisasi publik, sehingga publik harus mengetahui bentuk kaderisasi, program, serta keuangan parpol. Sehingga indikator transparansi dapat diterapkan dalam pertanggungjawaban Partai.

Pertanggung jawaban (akuntabilitas) keuangan yang digunakan untuk kampanye tidak pernah terlaporkan secara transparan atau tepat. Sumber penerimaan dana kampaye beserta belanja dana kampanye diduga tidak sesuai antara yang dilaporkan ke Komisi Pemilihan Umum (KPU) dengan kondisi riilnya (beritasatu.com:2018). Pada kenyataannya laporan hanya untuk menggugurkan kewajiban saja, sehingga dana yang "membahayakan" tidak akan diungkapkan dalam pertanggungjawabannya.

Audit dana kampanye hanyalah sebatas audit kepatuhan, yaitu hanya berdasar atas kesesuaian bukti dan ketentuan yang sudah dierangkan dalam 
Peraturan KPU maupun undang-undang, auit tersebut tidak sampai kepada audit investigasi. Sanksi yang diberikan oleh KPU akibat tidak patuhnya suatu partai terhadap aturan yang telah ditetapkan memang sangat jelas dan sangat berdampak, sehingga partai berbondongbondong mematuhinya agar dapat menghindari sanksi. Harusnya fenomena ini juga berlaku untuk akuntabilitas partai diluar pelaksanaan Pemilu.

Mardiasmo (2019) menjelaskan bahwasanya Akuntabilitas atau pertanggung jawaban ialah suatu kewajiban untuk menunjukkan keberhasilan maupun kegagalan secara tepat mengenai pelaksanaan misi maupun tujuan beserta sasaran yang telah ditetapkan sebelumnya, melalui suatu wadah pertanggungjawaban yang dilaksanakan secara periodik dan berkelanjutan.

Kepatuhan dan transparansi tidak hanya diterapkan dalam laporan dana kampanye, namun semua hal yang berkaitan dengan partai politik. Untk menerapkannya, kader parpol harusnya mendapatkan pendidikan yang memadai. Laporan keuangan parpol bukan surat sakti yang rahasia, tapi memang harus dipublikasikan sebagai bentuk akuntabilitas publik, mengingat partai politik merupakan organisasi publik.

Contoh pentingnya akuntabilitas dan transparansi menurut halim dan kusufi (2018) yaitu kenyataan bahwa parti politik memang sedikit banyak ditunggangi oleh beberapa kepentingan kelompok yang sangat sulit dihindari, hal itu disebabkan karena partai politik selama ini hidup dari dukungan masyarakat. Kelangsungan hidup partai politik sangat tergantung pada sumbangan pihak-pijak yang berkepentingan.Kemandirian partai politik sangat penting dan sangat mempengaruhi independensi partai politik itu sendiri, namun hal tersebut sulit dilakukan. Solusi terbaik adalah menciptakan sistem yang transparansi dan bertanggungjawab dalam hal pencatatan sumber dana tersebut. Seluruh sumbangan harus tercatat lengkap dengan idenntitas penyumbang.

Laporan dana kampanye yang dilaporkan oleh parpol kepada KPU belum menggambarkan aktivitas pembiayaan kampanye yang sesungguhnya. Terdapat beberapa hal yang menyebabkan akuntabilitas dana kampanye belum optimal, yaitu aspek budaya dalam organisasi parpol itu sendiri dan aspek lemahnya pertanggungjawaban pengelolaan pendanaan partai politik itu sendiri (beritasatu.com:2018)

Teori agensi melekat pada organisasi sektor publik. Dimana dalam partai politik, adanya sumbangan dari anggota parpol itu sendiri ataupun 
perorangan dan badan dari eksternal partai merupakan sumber dana utama. Setiap orang ataupun badan yang memberikan dananya kepada parpol pastilah memiliki kepentingan yang ingin di akomodir oleh partai tertentu, sehingga disini pentingnya masyarakat menuntut akuntabilitas yang transparan bagi parpol sebagai organisasi publik.

Mewujudkan good political party governance harus dimlai dari kesadaran pengurus partai terlebih dahulu untuk selalu menyajikan data dan laporan secara transparan, tidak hanya patuh pada saat pelaksanaan pemilu namun berkelanjutan dan terus menerus. Tidak hanya takut terhadap sanksi secara langsung yang ditetapkan oleh KPU, namun juga memperhatikan kelanjutan dan keberlangsungan partai politik. Going concern tidak hanya berlaku pada entitas bisnis, melainkan juga penting berlaku pada organisasi partai politik. Partai politik merupakan wadah berkumpulnya kader yang menjadi dan atau masih akan menjadi pejabat publik yang nantinya mengemban amanah dan bekerja untuk rakyat, inilah alasan pentingnya akuntabilitas dan transparansi untuk tatakelola partai yang baik.

Kesulitan mengakses informasi dan laporan keuangan Parpol di Kabupaten Pamekasan menjadi bukti kurang sadarnya pengurus Parpol terhadap transparansi dan tatakelola partai politik. Mereka hanya takut terhadap sanksi KPU pada saat pelaksanaan Pemilu saja.

\section{KESIMPULAN DAN SARAN}

Kunci dari suksesnya penerapan good Political Party Governance adalah sistem dan SDM. Adanya komitmen yang tinggi antara pengurus partai pusat sampai daerah mengenai kesadaran utama bahwasanya Partai Politik merupakan organisasi nirlaba dimana pertanggung jawabannya kepada publik. Partai Politik memiliki beban moral untuk mengedukasi masyarakat dan semua stakeholder bahwa organisasinya merupakan organisasi yang akuntabel dan amanah. Sehingga sumber pendanaan dan pengeluaran dananya sangat penting untuk dipublikasikan kepada publik secara transparan. Going concern tidak hanya berlaku pada entitas bisnis, melainkan juga penting berlaku pada organisasi partai politik. Partai politik merupakan wadah berkumpulnya kader yang menjadi dan atau masih akan menjadi pejabat publik yang nantinya mengemban amanah dan bekerja untuk rakyat, inilah alasan pentingnya akuntabilitas dan transparansi untuk tatakelola partai yang baik.

Adapun saran bagi peneliti selanjutnya hendaklah meneliti lebih fokus pada transparansi sumber dana partai politik. Dimana sumber dana 
dapat mempengaruhi sikap partai politik

dalam kontribusinya kepada negara dan rakyat.

\section{DAFTAR PUSTAKA}

Abdullah dan Abdul Halim. 2006. Studi Atas Belanja Modal pada anggaran pemerintah daerah.

Agusta I. 20003. Teknik Pengumpulan Dan Analisis Data Kualitatif.

Donaldson,L.,dan Davis, J.H.1991. Stewardship Thery or Agency Theory: CEO Governance and Sharehlder returns. Australian Journal

Dwikora, Putu Wirata. 2016. Menuju Akuntabilitas Partai Politik. Udayana University Press. Denpasar.

Halim, Abdul dan Muhammad Syam Kusufi. 2018. Teori, Konsep, dan Aplikasi Akuntansi Sektor Publik. Salemba Empat. Jakarta.

Panlih, Sekar Anggun Gading. 2017. Mendorong Transparansi dan Akuntabilitas Pengaturan Keuangan Partai Politik. Mimbar Hukum Vol. 29 No.1 Hal 69 - 81
Patton, Michael Quinn.1991.Metode Evaluasi Kualitatif, Terjemah : Budi Puspo. Priyadi. Pstaka Pelajar : Yogyakarta

Peraturan KPU No. 24 Tahun 2018 Tentang Dana Kampanye.

PSAK No.45 (Revisi 2014) : Pelaporan Keuangan Entitas Nirlaba. Jakarta:IAI

Undang-undang No 02 Tahun 2008 tentang Partai Politik

Undang - undang No 02 Tahun 2011 Tentang Perubahan atas Undang-undang No 02 Tahun 2008 tentang Partai Politik

Wibowo, Eka Adhi. 2018. Akuntabilitas Partai Politik dan Elektbilitas Partai Politik: Studi Kasus Partai Politik Peserta Pemilu di Propinsi DIY Tahun 2014. JRAK Vol. IV. No. 1

https://www.Nasional.Kompas.com

https://madura.tribunnews.com/2019/05/ 07/laporan-pengeluaran-danakampanye-tak-kunjungdiserahkan-kpu-pamekasanakan-beri-sanksi-partai-ini

https://www.beritasatu.com/politik/5124 37/akuntabilitas-danakampanye-lemah 